\title{
Zoonosis associated to Rattus rattus and the impacts of the public actions to control the species
}

\author{
Zoonoses associadas à Rattus rattus e os impactos das ações públicas de \\ controle sobre a espécie
}

\author{
Lilian dos Santos Babolin', Maria Jeovânia Freire de Almeida-Silva², \\ Marcos Roberto Potenza ${ }^{2}$, Claudia Del Fava ${ }^{3}$, Vanessa Castro ${ }^{3}$, Ricardo Harakava ${ }^{4}$, \\ Liria Hiromi Okuda ${ }^{3}$, Marcia Maria Rebouças ${ }^{5}$, Ana Eugênia de Carvalho Campos ${ }^{2 *}$
}

\begin{abstract}
The occurrence of the black rat, Rattus rattus, in major Brazilian cities has increased in the recent years. To evaluate if the efforts of public rodent control have been reaching the species in the city of São Paulo, a survey was conducted in flooding areas using live trapping before and after implementation of the control program. Captures were carried out from 2009 to 2011, and animals were evaluated for their risk of zoonosis transmission. The number of $R$. rattus captured after control did not differ from the number of animals captured before the control program in the Spring/Summer season, but, in the Autumn/Winter season, effective control was observed. Low infestations of Ctenocephalides felis (Siphonaptera) and Echinolaelaps echidninus (Acarina) were observed, and antibodies against Leptospira spp. were detected in just 1 of 65 serum samples. Ten out of 18 serum samples were sororeactive for Vaccinia virus, suggesting contact between $R$. rattus and the pathogen Calodium hepaticum (= Capillaria hepaticum) (Nematoda) was found in the liver of $73.4 \%$ of captured $R$. rattus. In conclusion, $R$. rattus may not be effectively controlled by the rodent Control Program in the city of São Paulo, and represents a threat to human health, justifying permanent environmental management and educational programs.
\end{abstract}

KEYWORDS: Rodentia; Leptospira; Vaccinia virus; Siphonaptera; Acari; Calodium hepaticum.

\begin{abstract}
RESUMO: A ocorrência do rato de telhado, Rattus rattus, nas grandes cidades brasileiras aumentou nos últimos anos. A fim de investigar se os esforços do controle público de roedores têm atingido essa espécie, foi conduzido um levantamento em áreas com risco de inundação na cidade de São Paulo, com armadilhas para captura viva dos roedores, antes e depois do controle público. O estudo foi realizado entre 2009 e 2011, e os animais capturados foram estudados para identificar seu risco como transmissores de zoonoses. O número de $R$. rattus capturados após o controle não diferiu entre o número de animais capturados antes do programa de controle, no período de primavera/verão, mas, no período de outono/inverno, foi observada efetividade do controle. Foram registradas infestaçôes baixas de Ctenocephalides felis (Siphonaptera) e Echinolaelaps echidninus (Acarina). Anticorpos contra Leptospira spp. foram detectados em apenas 1 das 65 amostras de soro. Dez entre 18 amostras de soro foram sororeativas para o vírus Vaccinia, sugerindo o contato entre $R$. rattus e o patógeno Calodium hepaticum (Nematoda) foi encontrado no fígado de $73,4 \%$ dos $R$ rattus capturados. Concluiu-se que $R$ r rattus pode não ser controlado pelas ações propostas pelo Programa de Controle de Roedores na cidade de São Paulo e representa uma ameaça para a saúde humana, justificando permanentes programas de gestâo ambiental e programas educacionais.
\end{abstract}

PALAVRAS-CHAVE: Rodentia; Leptospira; vírus Vaccinia; Siphonaptera; Acari; Calodium hepaticum.

'Prefeitura Municipal de São Paulo, Secretaria Municipal de Saúde, Coordenação de Vigilância em Saúde, Centro de Controle de Zoonoses. Subgerência de Vigilância, Prevenção e Controle da Fauna Sinantrópica - São Paulo (SP), Brazil.

Unidade Laboratorial de Referência em Pragas Urbanas, Instituto Biológico -São Paulo (SP), Brazil.

${ }^{3}$ Centro de Pesquisa e Desenvolvimento em Sanidade Animal, Instituto Biológico - São Paulo (SP), Brazil.

${ }^{4}$ Centro de Pesquisa e Desenvolvimento em Sanidade Vegetal, Instituto Biológico - São Paulo (SP), Brazil.

${ }^{5}$ Centro de Comunicação e Transferência do Conhecimento, Instituto Biológico - São Paulo (SP), Brazil.

*Corresponding author: anaefari@biologico.sp.gov.br

Received on: 09/30/2014. Accepted on: 12/11/2015 


\section{INTRODUCTION}

The urban environment promotes close contact between rats and people (Himsworth et al., 2013), which can increase the risk of zoonotic disease transmission throughout the world. The three most common rodent species in urban areas worldwide are Rattus norvegicus (Berkenhout, 1769), Rattus rattus (Linnaeus, 1758) and Mus musculus (LinNaEus, 1758). Rodent control is usually under the responsibility of public entities and/or pest control companies, as a service to people and companies that can afford the service.

The occurrence of the black rat, $R$. rattus, in major Brazilian cities has increased in the recent years (Masi et al., 2009), and it is not clear whether the rodent control provided by public programs has affected this rat species. Rodent control programs in Brazil focus mainly on the Norway rat $(R$. norvegicus), which presence is associated with leptospirosis due to the high rat population density, large low-income human population, poor sanitary conditions and constant flooding in some areas. In some properties, as schools, day care centers and other public buildings, $R$. rattus is also controlled.

The two Rattus species differ in their behavioral aspects: while black rats tend to enter human dwellings through holes in the roof, cracks in walls or ceilings, or access points near utility lines, Norway rats tend to enter structures through sewage systems, as well as cracks or holes in a building's foundations (MAsi et al., 2009; MARSH, 1994).

In the city of São Paulo, Brazil, the public rodent control program is conducted in public areas. Chemical treatments consist of three applications at seven to ten-day intervals. Three anticoagulant rodenticides have been used in three formulations: a dry powder (Coumatetralyl 0.75\%) applied within burrows, granulated baits (Brodifacum $0.005 \%$ ), and paraffin-type bait blocks (Bromadiolone $0.005 \%)$ applied mainly to culverts. In order to estimate rodent populations, the rodent control program evaluates the presence of feces, rub marks, burrows, gnawing, and rat trails (MAsI et al., 2009). Live traps are not normally used despite being useful tools to assess information on the prevalent species, their distribution and habits, sex ratios and age structure, as well as to evaluate the presence of pathogens that can be spread by these synantropic animals.

As both rodent species occur in the city of São Paulo, we evaluated if the actions of the rodent program methods is controlling the population of the black rat in the city, as well as the presence of Leptospira, zoonotic poxviruses, endo and ectoparasites, which can be a threat to human health.

\section{MATERIALS AND METHODS}

\section{Study areas}

The government of São Paulo city is divided into 31 subprefectures responsible for different city districts. This study was conducted in the area under responsibility of three subprefectures (Itaquera, Aricanduva and Lapa) (Fig. 1) selected for the presence of confirmed cases of leptospirosis with human deaths, high rates of rodent infestation, and historical floods (Masi et al., 2009).

\section{Rodent survey upon the public rodent control program on Rattus rattus}

Itaquera subprefecture, which contains four districts (Cidade Líder, Itaquera, José Bonifácio and Parque do Carmo), was the chosen for this part of the study (Fig. 1). Each district contains areas designated for the rodent control program. One program area was selected randomly in each district. Properties, in each program area, were selected randomly where live trapping was conducted to evaluate efficacy of rodent control program. If selected properties were closed or if the owner denied access, we surveyed one of the two next properties to the right or to the left.

Live captures were conducted with the authorization of the Ethics Committee on Animal Experimentation of Instituto Biológico (CETEA-IB) under the number 085/09. Captures

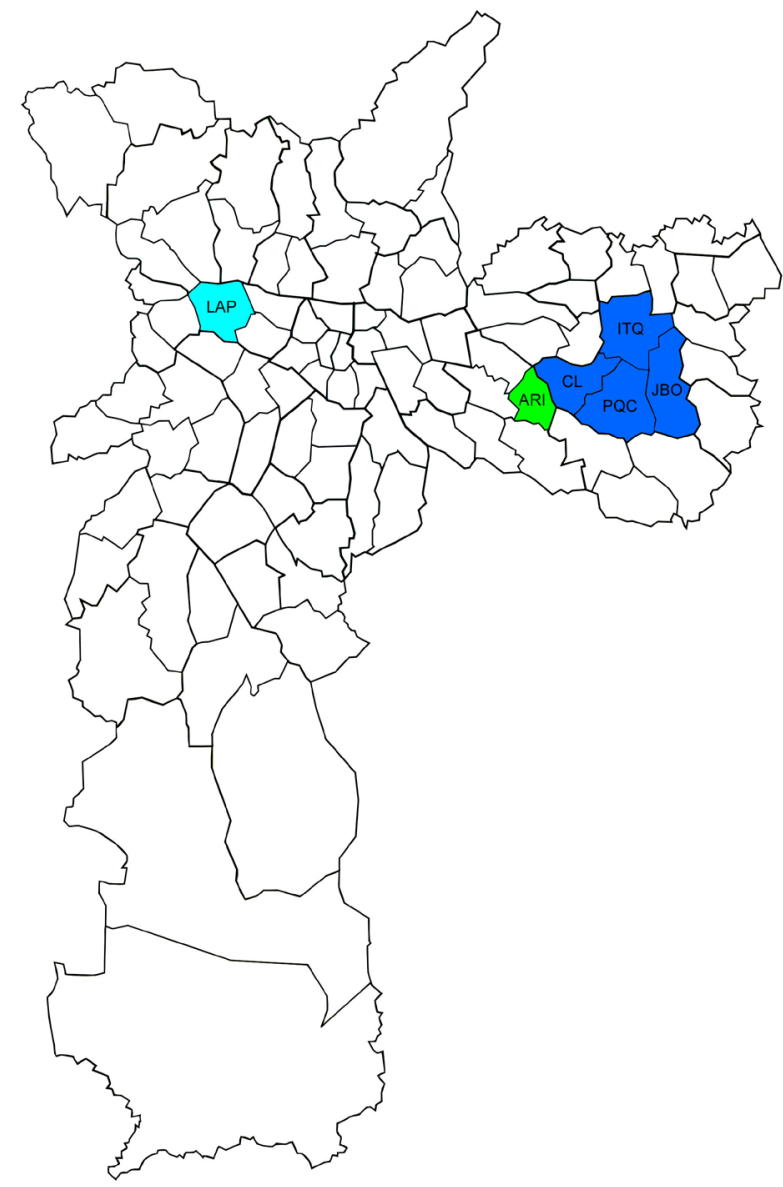

LAP: Lapa; ARI: Aricanduva; ITQ: Itaquera; PQC: Parque do Carmo; JBO: José Bonifácio; CL: Cidade Líder.

Figure 1. Districts in the city of São Paulo where rodent live captures were carried out. 
were conducted in two periods, Autumn/Winter 2009 (April/ September) and Spring/Summer 2009/2010 (September/ March), based on Spaulding; JaCKson (1983) and CDC (2006). Captures were done 15 days before and 15 days after the public rodent control actions. One Tomahawk trap $(53 \times 23 \times 22 \mathrm{~cm})$ was placed in each of the 20 selected properties of the 4 districts for a total of 80 collection addresses, with a total of 320 traps.

In order to minimize neophobia, traps were left on each address for seven consecutive days without baits and disarmed prior to capture attempts.

Traps were set next to the outside wall of the structure and were baited with banana, cereal and cat or dog food. Once a rodent was captured, the trap was taken to the laboratory, where the animal was euthanized with dioxide carbon $\left(\mathrm{CO}_{2}\right)$ (American Veterinary Medical Association, 2007). Animals were immediately examined for the species identification, phase of development and sex. The McNemar test (at $\alpha=0.05$ ) was used to evaluate rodent populations based on trapping before and after the control program.

\section{Ectoparasites, endoparasites and other pathogens associated to rodents}

\section{Rodent captures}

Two other subprefectures, Aricanduva and Lapa (Fig. 1), were used for rodent captures in order to evaluate the presence of ectoparasites, endoparasites and other pathogens, besides rodents captured in Itaquera that were also analyzed. The two new areas were chosen to increase our samples, and in places other than households.

Properties located in the subprefecture of Aricanduva were randomly selected as described before for the subprefecture of Itaquera. In the subprefecture of Lapa, captures were done in a whosale and warehousing center. Captures, in both Aricanduva and Lapa, were conducted during Fall/Winter 2010 (April/September) and Spring/Summer (September/March) 2010/2011. Four Tomahawk ${ }^{\circ}$ traps were left at each capture site for a total of 240 traps. Traps were armed, baited, and left on the sites for 15 days, or until a rodent was captured. Animals were then euthanized and identified as described above for rodents captured in Itaquera.

\section{Ectoparasites}

Captured and euthanized rodents were immediately washed with $90 \%$ ethanol, and brushed for ectoparasite removal. When found, arthropods were stored in vials containing 70\% ethanol before mounting on slides and identification.

\section{Parasites and other pathogens}

During necropsy of the animals, samples of blood and organs were obtained in order to determine the presence of pathogens.
All procedures with rodents were done in a Class II, Type B2 biological safety cabinet.

The Microscopic Aglutination Test (MAT) was used for the diagnosis of leptospirosis on serum samples with a battery of 22 live antigens representing the main pathogenic serogroups of Leptospira species (FAINE et al., 1999). The isolation of Leptospira spp. from internal organs was performed according to the protocol of specific culture medium (Alves et al., 1996). Fragments of kidney and liver were macerated in homogenizer (Stomacher 80), and resuspended in TE buffer $(10.0 \% \mathrm{w} / \mathrm{v})$ for Polymerase Chain Reaction (PCR) analysis.

The presence of Vaccinia virus was determined through the neutralizing antibodies assay using the Araçatuba Virus strain (VACV ARAV), and samples were considered seroreagent if the titer was $\geq 4$. Only 18 rodents were tested using the Virus Neutralizing Technique, because sufficient blood serum $(50 \mu \mathrm{L})$ for serology could not be obtained from other animals. PCR was used for identification and characterization of Vaccinia in organs (Damaso et al., 2007).

Histopathological analyses were conducted on 13 of the $14 R$. rattus captured in Itaquera, because 1 animal had to be excluded due to autolysis, and on all 51 animals collected in Aricanduva and Lapa. Fragments of organs (liver, spleen, kidneys and heart) collected at necropsy were fixed in 10\% buffered formalin for 48 hours. Subsequently, the samples were subjected to processing and staining with hematoxylin and eosin (Ricci; PAdín, 1980). The histopathological interpretation was based on inflammatory and degenerative lesions, and presence of parasitic structures viewed through optical microscope.

\section{RESULTS}

\section{Capture success before and after public rodent control program}

The 320 traps placed in the subprefecture of Itaquera during the 2 periods of collection (160 traps either before or after rodent control) successfully captured rats during Autumn/ Winter 2009, and in the Spring/Summer 2009 - 2010 before and after the public rodent control program, in the different seasons (Table 1). Sixteen rodents were captured during the study: $14 R$. rattus, and 1 each of $M$. musculus and $R$. norvegicus.

The rats were captured from 1 to 14 days after trap placement. The rodent trapped on the first day was a $R$. rattus female young animal. No consumption was observed on baits infested by insects, dirt or mold, unlike intact baits which were readily accepted by the rodents.

In Lapa and Aricanduva, $22.0 \%$ of the 240 traps captured rodents including $1 R$. norvegicus and $51 R$. rattus. Animals were captured from 1 to 4 days after traps placement. 
Fewer rodents were captured in the Autumn/Winter 2009 after control $(\mathrm{p}=0.034)$, but no differences were observed between the numbers of rodents captured before and after control efforts in the Spring/Summer 2009/2010 in Itaquera $(\mathrm{p}=1.000)$ (Table 1). Young and female rodents were captured in both Autumn/Winter and Spring/Summer seasons.

\section{Ectoparasites, parasites and other pathogens}

The mite Echinolaelaps echidninus (BERLESE, 1887) (Acarina: Laelapidae) was found on $R$. rattus collected in Itaquera, Aricanduva and Lapa. A maximum of 14 mites were collected per animal. The cat flea, Ctenocephalides felis (BoucHÉ, 1835) (Siphonaptera: Pulicidae) was also found on the black rats (Table 2).

None of the 14 serum samples from the black rats captured in Itaquera, or the 51 R. rattus captured in Aricanduva and Lapa, was seropositive for any of the 22 Leptospira sorovars (Table 2). Despite identification of 9 suspected Leptospira samples from Aricanduva and Lapa through isolation in culture medium, PCR results were negative, except for 1 sample from Itaquera.

None of the $R$. rattus samples was positive through viral isolation or PCR for Vaccinia virus, but 10 samples from 18 (55.6\%) from the subprefecture of Aricanduva and 2 districts of Itaquera were seropositive and antibody titers varied from 4 to 32. Skin lesions or macroscopic alteration in the internal organs related to poxvirus disease were not observed in the seropositive animals.

Table 1. Success of rodent capture before and after the rodent public control program in the district of Itaquera, city of São Paulo. 2009 - 2010.

\begin{tabular}{|c|c|}
\hline Season of rodent capture & $\begin{array}{c}\text { Success of } \\
\text { capture } \\
(n=160)\end{array}$ \\
\hline \multicolumn{2}{|c|}{ Before Rodent public program control } \\
\hline Autumn/Winter & $8.75 \%$ \\
\hline Spring/Summer & $6.67 \%$ \\
\hline \multicolumn{2}{|c|}{ After rodent public program control } \\
\hline Autumn/Winter & $1.65 \%$ \\
\hline Spring/Summer & $6.67 \%$ \\
\hline
\end{tabular}

Table 2. Percentage of parasitized/seroposite for leptospirosis rodents captured in different districts in the city of São Paulo, Brazil, from 2009 to 2011.

\begin{tabular}{lcc} 
& \multicolumn{2}{c}{$\begin{array}{c}\text { Percentage of parasitized } \\
\text { rodents/seropositive }\end{array}$} \\
\cline { 2 - 3 } Ectoparasite/parasite & $\begin{array}{c}\text { Itaquera } \\
\text { (14 R. rattus) }\end{array}$ & $\begin{array}{c}\text { Aricanduva/Lapa } \\
\text { (51 R. rattus) }\end{array}$ \\
\hline Echinolaelaps echidninus & $21.43 \%$ & $5.88 \%$ \\
\hline Ctenocephalides felis & $7.14 \%$ & $1.96 \%$ \\
\hline Calodium hepaticum & $53.80 \%$ & $78.40 \%$ \\
\hline
\end{tabular}

Elliptical eggs with operculate poles in different states of maturation, with thick walls in differentiated layers, as well as sections of nematode parasites, were observed in histological samples (Fig. 2). All parasitic stages were found near the liver portal spaces, and were identified as Calodium hepaticum (Nematoda: Capillariidae) (BANCroft, 1893) (Nematoda). Connective tissue associated with mononuclear infiltrate and eosinophils was observed around eggs and parasites. Liver tissues also showed alteration of lobular architecture, trabecular disarray, as well edemas with serous accumulation in some fields and hydropic degeneration of some hepatocytes near the parasites and eggs. Some lesions with eggs and parasites were calcified. Eggs and parasites were observed in the liver of the animals from the three studied districts (Table 2).

\section{DISCUSSION}

Our data registers $R$. rattus as the primary rodent species in São Paulo, as revealed previously from feces, rub marks, burrows, gnawing, and rat trails (Masi et al., 2009). The size of the used traps can capture young $R$. norvegicus (Potenza personal communication), what could be a doubt in our findings on the low capture of this species and the high success in capturing $R$. rattus.

The success of live capture depends on the environment, presence of people and predators, weather conditions, biology of rodents, and their preferences for different baits. The capture success in this study can be considered high, especially in the subprefectures of Aricanduva and Lapa, given the neophobia normally seen in the rat population in relation to traps newly placed in the environment (BrasiL, 2002), which leads to low capture rates. Neophobia is one of the main reasons for low

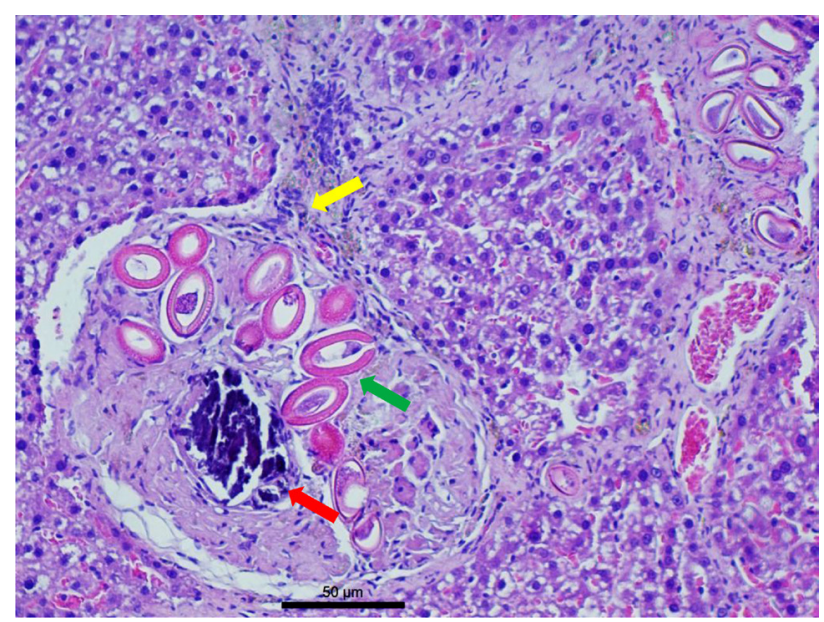

Figure 2. Rattus rattus - liver: portal spaces with Calodium hepaticum (Capillaria hepatica) ova in different stages of maturation (green arrow), and a calcified nematode (red arrow), circumscribed by connective tissue (fibrotic area) associated with mononuclear inflammatory cells (yellow arrow). 
capture rates (MAsI et al., 2009), because, when a rodent is captured, the animal is exposed to the other members of the group decreasing trapping efficacy. Due to poor sanitary conditions observed in all sampling sites, great number of hiding places and garbage were available in the vicinity where traps were placed, providing essential conditions for the establishment of rodent populations (Himsworth et al., 2013).

Infestation of baits by insects and the presence of dirt or mold on baits may have influenced rodent control (CALDAS et al., 2011). The warm and humid Spring and Summer seasons in São Paulo favor fungal growth on baits. Fungal contamination of rat baits can degrade paraffin blocks, the most common formulation used for rodent control in Sáo Paulo. When baits are placed in culverts and similar sites, despite efforts to prevent contact with water, moisture levels promote fungal growth on the baits (BRASIL, 2002), and potentially change rodent acceptability and consequent efficacy on the control despite the lack of change in bromadiolone concentration (PAPINI et al., 2011).

Rodenticide use has an important role in some circumstances, for instance, in an outbreak of disease or for the initial reduction of a large rodent population. But it should not be used as the main strategy on rodent control. The environment management must be used, and should be the main strategy. The studied areas were ambientally deteriorated, with a great offer of food and hiding places, and, along with ideal temperature and humidity, $R$. rattus and $R$. norvegicus populations can rapidly increase again after control programs made by the municipality, especially after warmer seasons.

Once established a rodent population, the associated ectoparasites may be a secondary problem. Results showed a low number of ectoparasites on the captured black rats, one mite and one flea species. E. echdininus is a common mite on black and Norway rats, called the spiny rat mite, that can parasite man and cause dermatitis. It serves as the definitive host of Hepatozoon muris (BALFORD, 1905), a haemogregarin (protozoan) which infect rats (STRANDTMANN; Wharton, 1958). E. echidninus experimentally also houses Francisella tularensis (MCCoy; CHAPIN, 1912), the causative agent of tularemia (Larsson et al. 2005). However, its role as an agent of zoonosis to humans is uncertain. C. felis may promote dermatitis and causes irritation on human skin. Occasionally, it can transmit Dipylidium caninum (Linnaues, 1758) to man. Few fleas were also obtained from black rats captured in Panama, Florida, EUA (Durden et al., 2000), but a higher number of insects was collected from $R$. rattus in California -827 fleas belonging to 8 species, from 1,206 black rats (Schwan et al., 1985). The species of most concern flea was not found, Xenopsylla cheops, which can transmit Yersinia pestis (Lehmann; Neumann, 1896) and Rickettsia typhi (Wolbach and Todd 1920).

Leptospirosis is one of the most important diseases transmitted by rodents in urban areas (Evangelista; Coburn, 2010).
In order to isolate the bacterium, it is necessary to have both viability and minimal interference from contaminants in the samples. PCR is used successfully from any clinical material and allows specific identification of the microbial DNA, with high sensitivity and promptitude. For leptospirosis, this technique is essential when the isolation is difficult, especially in the absence of viability (GeNOvEZ, 2006). Not unexpectedly, only one animal was seropositive to leptospirosis in this study, because $R$. rattus is a lesser frequent reservoir for Leptospira spp. than $R$. norvegicus (Lindenbaum; Eylan, 1982), and its capacity to transmit the disease is low. However, because the number of black rats captured was not changed by the rodent control efforts, $R$. rattus's capacity to a vector for Leptospira, though small (BrasIL, 2009), was not changed by control efforts. Because the study sites are regularly afflicted by floods, human residents may become infected through direct contact with rat urine or indirectly through contact with contaminated soil or water (Evangelista; Coburn, 2010).

The transmission of Vaccinia virus to humans is also an important consideration in rat control programs because wild rodents are natural reservoirs of this pathogen. The virus has been detected in the state of Sáo Paulo (Fonseca et al., 2002) and (AвRAHÁo et al., 2009), and is frequently detected in rural areas affecting both humans and cattle, with considerable effect on the milk supply chain. A high Vaccinia infection rate in rats captured in the city of São Paulo is worrisome and highlights the importance of further studies to evaluate potential public health impacts and how this virus reached in the urban area. The expansion of agriculture in areas near urban centers or the urban sprawl into tradition rural areas can contribute to the spread of Vaccinia virus among urban rodents.

$R$. rattus is an important reservoir for $C$. hepaticum, a zoonotic nematode parasitizing in the liver of more than 30 mammal species, dogs, cats, swines, monkeys, rabbits and commonly rodents (KoHATsu et al., 1995). It is the causative agent of the rare condition of hepatic capillariosis and spurious $C$. hepaticum infections in humans. FueHrer et al. (2011) reported 163 cases of infestations with this parasite ( 72 reports of hepatic capillariosis, 13 serologically confirmed infestations and 78 observations of spurious infections).

From 138 R. norvegicus captured in Salvador, Brazil, 56.5\% were parasitized by C. hepaticum (Galvão, 1976), and in the city of Sáo Paulo, 59\% from 205 rodents ( $R$. norvegicus and $R$. rattus) were also parasitized (CHIEFFI et al., 1981). Records of the nematode were also recently registered in the city of Belém, in Eastern Amazon (Moreira et al., 2013). In most rodents, infection by $C$. hepaticum ranges from mild to severe, but it is not associated with a clinical disease. The presence of $C$. hepaticum in the liver of $R$. norvegicus analyzed by SPRATT; SINGLETON (2001) showed no signs of systemic changes consistent with liver failure, which corroborates to the hypothesis that the rats act as primary hosts of $C$. hepaticum and are the main reservoirs of the parasite in many urban areas. 
In relation to the parasitic nematode, a high density of rats ensures a continuous stock of $C$. hepaticum eggs, resulting in increasing severity of the $C$. hepaticum infection in the rat population and the high likelihood of human contact with infective eggs. Low rodent population density results in lower parasitic load on the host species. Thus, an assessment of the prevalence and intensity of infection with $C$. hepaticum establishes an indirect indication of population density of rats (Spratt; Singleton, 2001). The high success of $R$. rattus capture in our study, along the high number of rodents parasitized by $C$. hepaticum, corroborates these authors' statements and concerns about the black rat in urban areas because known human cases of infection with $C$. hepaticum are generally severe or fatal. Although $C$. hepaticum has a worldwide distribution, the incidence and prevalence of human capillariosis are rather low (Fuehrer et al., 2011), but, if misdiagnosed, C. hepaticum can cause severe hepatic capillariosis which may lead to the patient's death.

\section{CONCLUSIONS}

This work confirms concerns about important zoonosis that may impact public health. The Vaccinia virus and the nematode $C$. hepaticum are considered in this study the most worrisome, once $55.6 \%$ from 18 samples of rodents were seropositive to the virus and $73.8 \%$ of 65 analyzed rodents showed the parasite. Despite identification of 9 suspected Leptospira samples from Aricanduva and Lapa through isolation in culture medium, PCR results were negative, except for 1 sample from Itaquera. In this way, $R$. rattus continues to show low importance on the leptospirosis transmission chain. The ectoparasites Echinolaelaps echidninus and Ctenocephalides felis felis were found and are considered as a secondary problem, once they may transmit zoonosis. The number of black rats captured in the study was not changed by the public rodent control efforts, at least in the Spring/Summer seasons. We suggest for the public program responsible entities that, even though they make $R$. rattus control in schools, day care centers and other public buildings, citizenships should be warned on the threats to health that this species of rodent can cause, once the capture success of the species was relatively high in this study.

\section{ACKNOWLEDGMENTS}

Authors thank Roberto Pereira from the Urban Entomology Laboratory, University of Florida, and Simone Aquino, from Uninove, for their help in improving the manuscript.

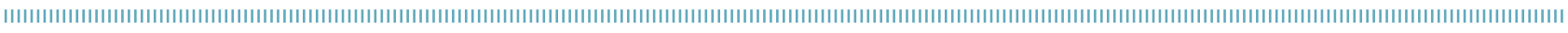
REFERENCES

ABRAHÃO, J.S.; GUEDES, M.I.; TRINDADE, G.S.; FONSECA, F.G.; CAMPOS, R.K.; MOTA, B.F.; LOBATO, Z.I.P.; SILVA-FERNANDES, A.T.; RODRIGUES, G.O.L.; LIMA, L.S.; FERREIRA, P.C.P.; BONJARDIM, C.A.; KROON, E.G. One more piece in the VACV ecological puzzle: could peridomestic rodents be the link between wildlife and bovine vaccinia outbreaks in Brazil? Plos One, v.4, n. 10, 2009.

ALVES, C.J; VASCONCELLOS, S.A.; CAMARGO, C.R.A.; MORAIS, Z.M. Influência dos fatores ambientais sobre a proporção de caprinos soro-reatores para a leptospirose em cinco centros de criação do Estado da Paraíba, Brasil. Arquivos do Instituto Biológico, São Paulo, v.63, n.2, p. 11-18, 1996.

AMERICAN VETERINARY MEDICAL ASSOCIATION (AVMA). AVMA Guidelines on Euthanasia, 2007. Available from: <https://www.avma. org/KB/Policies/Documents/euthanasia.pdf>. Cited in: 12 Mar. 2009.

BRASIL. Ministério da Saúde. Manual de controle de roedores. Brasília: Fundação Nacional de Saúde, 2002. 130p.

BRASIL. Ministério da Saúde. Guia de vigilância epidemiológica. Ministério da Saúde, Secretaria de Vigilância em Saúde, Departamento de Vigilância Epidemiológica. 7. ed. Brasília: Ministério da Saúde, 2009. 813p. (Série A. Normas e Manuais Técnicos).
CALDAS, C.C.; JESUS, R.P.; POTENZA, M.R.; AQUINO, S. In: Robinson, W.H.; Campos, A.E.C. (eds). Proceedings of the 7th International Conference on Urban Pests. 2011 . Available from: <http://www.icup.org.uk/icupsearchres.asp?snum=0>. Cited in: 5 Dec. 2011.

CENTERS FOR DISEASE CONTROL AND PREVENTION (CDC). Integrated Pest Management: conducting urban rodent surveys, 2006. Available from: <http://www.cdc.gov/nceh/ehs/Docs/ IPM_Manual.pdf>. Cited in: 12 Mar. 2009.

CHIEFFI, P.P.; DIAS, R.M.D.S.; MANGINI, A.C.S. Capillaria hepaticum (Bancroft, 1893) em murídeos capturados no Município de São Paulo, SP, Brasil. Revista do Instituto de Medicina Tropical, v.23, n.4, p.143-146, 1981.

DAMASO, C.R.; REIS, S.A.; JESUS, D.M.F.X.; LIMA, P.S.F.; MOUSSATCHÉ, N. A PCR-based assay for detection of emerging vaccinia-like viruses isolated in Brazil. Diagnostic Microbiology and Infectious Diseases; v.57, p. 39-46, 2007.

DURDEN, L.A.; HU, R. OLIVER JR, J.H.; CILEK, J.E. Rodent ectoparasites from two locations in northwestern Florida. Journal of Vector Ecology, p. 222-228, 2000. 
EVANGELISTA, K.V.; COBURN, J. Leptospira as an emerging pathogen: A review of its biology, pathogenesis, and host immune responses. Future Microbiology, v.5, p. 1413-1425, 2010.

FAINE, S.; ADLER, B., BOLIN, C., PEROLA, P. Leptospira and leptospirosis. $2^{\text {nd }}$ ed. Melbourne: MediSci, 1999. 353p.

FONSECA, F.G.; TRINDADE, G.S.; SILVA, R.L.A.; BONJARDIM, C.A.; FERREIRA, P.C.P.; KROON, E.G. Characterization of a Vaccinia-like virus isolated in a Brazilian forest. Journal of General Virology, v.83, n. 1, p. 223-228, 2002.

FUEHRER, H.P.; IGEL, P.; AUER, H. Capillaria hepaticum in man an overview of hepatic capillariosis and spurious infections. Parasitology Research, v.109, p. 969-979, 2011.

GALVÃO, V.A. Capillaria hepaticum, estudo da incidência em ratos de Salvador, Bahia e dados imunopatológicos preliminares. Revista da Sociedade Brasileira de Medicina Tropical, v.10, p. 333-338, 1976.

GENOVEZ, M.E. Diagnóstico laboratorial de la leptospirosis animal. In: CACHIONE, R.A.; DURLACH, R.; LARGUI, O.P.; MARTINO, P. (eds). Temas de Zoonosis III. Buenos Aires: Ed. Asociacíon Argentina de Zoonosis, 2006. p. 170-182.

HIMSWORTH, C.G.; PARSONS, K.L.; JARDINE, C.; PATRICK, D.M. Rats, cities, people, and pathogens: a systematic review and narrative synthesis of literature regarding the epidemiology of rat-associated zoonosis in urban centers. Vector Borne Zoonotic Diseases, v.13, n.10, p. 1-11, 2013.

KOHATSU, H.; ZAHA, O.; SHIMADA, K.; CHIBANA, T.; YARA, I. SHIMADA, A.; HASEGAWA, H.; SATO, Y. A space-occupying lesion in the liver due to Capillaria hepaticum infection. American Journal of Tropical Medicine and Hygiene, v.52, n.5, p. 414-418, 1995.

LARSSON, P.; OYSTON, P.C.F.; CHAIN, P.; CHU, M.C.; DUFFIELD, M.; FUXELIUS, H.H.; GARCIA, E.; HÄLLTORP, G.; JOHANSSON, D.; ISHERWOOD, K.E.; KARP, P.D.; LARSSON, E. LIU, Y.; MICHELL, S.; PRIOR, J.; PRIOR, R.; MALFATTI, S.; SJÖSTEDT, A.; SVENSSON, K.; THOMPSON, N.; VERGEZ, L.; WAGG, J.K.; WREN, B.D.; LINDLER, L.E.; ANDERSSON, S.G.E.; FORSMAN, M.; TITBALL, R.W. The complete genome sequence of Francisella tularensis, the causative agent of tularemia. Nature Genetics, v.37, p. 153-159, 2005.

LINDENBAUM, I.; EYLAN, E. Leptospirosis in Rattus norvegicus and Rattus rattus in Israel. Israel. Journal of Medical Sciences, v. 18, n.2, p. 271-275, 1982.
MARSH, R.E. Roof rats. In: Hygnstrom, S.E.; TIMM, R.M.; LARSON, G.E. (eds.) Roof rats. Prevention and Control of Wildlife Damage. Lincoln: University of Nebraska, 2 vols. Paper 6; 1994. P. B125-B132.

MASI, E.; VILAÇA, P.; RAZZOLINI, M.T.P. Environmental conditions and rodent infestation in Campo Limpo district, São Paulo municipality, Brazil. International Journal of Health Research, v.19, n.1, p. 1-16, 2009.

MOREIRA, V.L.C.; GIESE, E.G.; SILVA, D.C.B.; MELO, F.T.V.; FURTADO, A.P.; MALDONADO JR. A.; SANTOS, J.N. Calodium hepaticum (Nematoda: Capillariidae) in synanthropic rodents (Rattus norvegicus and Rattus rattus) in Eastern Amazonia. Revista Brasileira de Parasitologia Veterinária, v.22, n.2, p. 265-269, 2013.

PAPINI, S.; PRISCO, R.C.B.; LUCHINI, L.C.; SAVOY, V.L.T.; VIEIRA, E.; NAKAGAWA, L. Avaliação da degradação do bromadiolona formulado como bloco parafinado e como pélete após exposição ambiental. Hygeia, Revista Brasileira de Geografia Médica e da Saúde, v.7, n.12, p. 90-97,2011.

RICCI, M.; PADÍN, S. Roedores transmisores de enfermidades: Medidas de prevención y control. Facultad de Ciencias Agrarias y Forestales Universidad Nacional de La Plata. 1980. Available from: <http://www.agro.unlp.edu.ar/institucional/secretarias/ extension/ publicacionestecnicas/roedoresp evencion.pdf $>$. Cited in: 22 Aug. 2010

SCHWAN, T.G.; THOMPSON, D.; NELSON, B.C. Fleas on roof rats in six areas of Los Angeles County, California: their potential role in the transmission of plague and murine typhus to humans. The American Journal of Tropical Medicine and Hygiene, v.34, n.2, p. 372-379, 1985.

SPAULDING S.R.; JACKSON, W.B. Field Methodology for Evaluating Rodenticide Efficacy. In: Kaukeinen, D.E. Vertebrate Pest Control and Management Materials: Fourth Symposium, ASTMSTP 817 , Philadelphia: American Society for Testing and Materials, 1983. p. 183-198.

SPRATT, D.M.; SINGLETON, G.R. Hepatic capillariasis In: Samuel, W.M.; Pybus, M.J.; Kocan, A.A. (Eds). Parasitic diseases of wild mammals. $2^{\text {nd }}$ ed. London: Manson Publishing/The Veterinary Press, 2001. p. 365-379. Available from: <http://books.google. com/books>

STRANDTMANN, R.W.; WHARTON, G.W. Manual of mesostigmatid mites parasitic on vertebrates. Maryland: Contribution 4 of The Institute of The Acarology, 1958. 69p. 